\title{
Rövid kitekintés az európai munkajog világát érintő, főbb közelmúltbeli jogesetek tükrében
}

\author{
A foglalkoztatás és a munkavégzés során alkalmazott \\ egyenlő bánásmód alkalmazásáról az Európai Unió \\ Bíróságának, valamint az Emberi Jogok Európai \\ Bíróságának gyakorlatából
}

\section{LOVÁSZY LÁSZLÓ GÁBOR ${ }^{1}$}

Az írás célja az Európai Unió Bírósága, valamint a strasbourgi Emberi Jogok Európai Bírósága által az elmúlt öt évben hozott, legfontosabb és legrelevánsabb itéletek áttekintése az egyes tagállamok vonatkozásában, tagállamonként, abc-sorrendben haladva. A szerzö fókusza a munka világában az egyenlö bánásmód területén felmerült ügyekre összpontosult, amelyek az adott tagállamban zajló kiemelkedö munkajogi jogvitákra terjedtek ki, különös tekintettel a hátrányos megkülönböztetés tilalmára. A szerzőnek nem szándéka az ismertetett itéletek minösitése, rendszerezése, mint ahogy az sem, hogy azokból akár jogi, akár társadalompolitikai következtetéseket vonjon le, vagy azokról összehasonlitó elemzést készitsen a terjedelmi korlátokra is figyelemmel. A tanulmány célja alapvetöen az EU-tagállamokban történt jogesetek rövid, mintegy felvillantásszerü ismertetése, listázása tanulságul, a konkrét esetek pedig referenciaként szolgálhatnak Magyarország és a magyar jogászok számára is a tágabb európai uniós és emberi jogi biráskodás gyakorlatának mélyebb áttekintése szempontjából, illetve egy-egy uniós tagállam munkajogi vitáinak gyors áttekintése érdekében.

Kulcsszavak: iszlám fejkendő viselésére vonatkozó tilalom, politikai, filozófiai és vallási semlegesség, fogyatékossággal élő munkavállalók elbocsátása, az elhízáson, életkoron, testmagasságon, valláson, béranyaságon vagy szerzetesi minőségen alapuló hátrányos megkülönböztetés, autonóm államigazgatási szerv, közvetett hátrányos megkülönböztetés, szakszervezeti jogok, közszférában foglalkoztatott munkavállalók, munkahelyi baleset

1 Tudományos főmunkatárs, Nemzeti Közszolgálati Egyetem Államtudományi és Nemzetközi Tanulmányok Kar Nemzetközi Kapcsolatok és Diplomácia Tanszék, e-mail: Lovaszy.Laszlo.Gabor@uni-nke.hu 


\title{
Short Overview of the European Labour Legislation through the Highlighted and Recent Cases for Equal Treatment in Employment and Occupation in Terms of the Case Law of the Court of the European Union and the European Court of Human Rights
}

\begin{abstract}
The aim of this short overview is to outline the most important as well as relevant decisions of the judicial forums covering the last five years for each Member State, in alphabetical order. The author's focus has been on issues arising in the field of equal treatment in the field of labour, which have covered outstanding labour law-related disputes in a given Member State, in particular the prohibition of discrimination. The author does not intend to classify and systematise the presented decisions, nor does it intend to draw any legal or socio-political conclusions from them, or to make a comparative analysis of them, due to the limits of the current study. The aim of the study is basically a short, flash-like description and listing of legal cases in the EU member states, and the specific cases can serve as a set of references for Hungary and Hungarian lawyers for a deeper understanding of the wider EU and human rights jurisprudence in order to provide a quick overview of labour law disputes in an EU Member State.
\end{abstract}

Keywords: ban on wearing an Islamic headscarf, political, philosophical and religious neutrality, dismissal of disabled workers, discrimination on grounds of obesity, age, height, religion, motherhood or monastic status, discrimination in employment, autonomous public administration, indirect discrimination workers, accident at work

Jelen írás célja, hogy átfogó, de egyúttal reményeim szerint könnyedén áttekinthető, kézzelfogható képet kapjunk az Európai Unió Bíróságának (EUB), valamint a strasbourgi Emberi Jogok Európai Bíróságának (EJEB) az elmúlt öt évben hozott, fontosabb ítéleteiről az egyes tagállamok vonatkozásában, a munka világában érvényesülö, az egyenlő bánásmód területén felmerült ügyeket illetően. Mint ahogy nincs két egyforma tagállam, úgy nincs két egyforma tagállami gyakorlat sem. Ezek kapcsán az EUB és az EJEB időről időre olyan ítéleteket hoz, amelyek a tagállami szabályozást, illetve gyakorlatot írják felül. Maguk az ügyek az adott tagállamban relevánsabb társadalmi, a jogviták tekintetében jellemzőbb folyamatait is némiképp visszatükrözik, további információkkal gazdagítva az egyes uniós országokról rendelkezésre álló ismereteket is. A terjedelmi korlátokra is figyelemmel az írásnak nem célja ezen ítéletek minősítése, rendszerezése - ezért tagállamonként, abc-sorrendben vesszük számba az ítéleteket -, mint ahogy az sem, hogy azokból akár átfogó jogi, akár társadalompolitikai következtetéseket vonjon le a jövőre nézve. A kizárólagosan külföldi, de EUtagállamokban történt jogesetek ugyanakkor tanulságul szolgálhatnak Magyarország számára az európai uniós és emberi jogi bíráskodás gyakorlatának áttekintése során. 
Kezdjük Belgiummal, a legtöbb európai uniós intézménynek otthont adó országgal! Az EUB előtt zajlott, 2017-ben zárult Achbita-ügy² kapcsán hozott ítélet alapján a foglalkoztatás és a munkavégzés során alkalmazott egyenlő bánásmód általános kereteinek létrehozásáról szóló, 2000. november 27-i 2000/78/EK tanácsi irányelvet (továbbiakban: 2000/78/EK irányelv) úgy kell értelmezni, hogy az iszlám fejkendő viselésére vonatkozó tilalom nem ütközik az uniós joggal. Ennek kiindulópontjául egy magánvállalkozás olyan belső szabályából keletkezett jogvita szolgált, amely alapján tiltották mindenfajta politikai, filozófiai vagy vallási jelnek a munkahelyen látható módon történő viselését. Az uniós bíróság azt állapította meg, hogy az ezen irányelv értelmében a tilalom nem minősül a valláson vagy meggyőződésen alapuló közvetlen hátrányos megkülönböztetésnek, ha a vállalkozás objektív módon igazolja, hogy ez az ügyfeleivel fenntartott kapcsolatok keretében politikai, filozófiai és vallási semlegességre vonatkozó szempont érvényesítését segíti elő. Egy másik, a Bougnaoui-ügyben az EUB ugyanakkor úgy határozott, hogy hátrányos és közvetlen megkülönböztetést szenved el a munkavállaló, ha az ügyfél arra vonatkozó kérését, hogy a munkáltató szolgáltatásait a továbbiakban ne iszlám fejkendőt viselő munkavállaló teljesítse, a munkáltató a munkavállaló elbocsátásával teljesíti, mert az irányelv a diszkrimináció tilalmától „valódi és meghatározó foglalkozási követelmény” esetén enged csak eltérést. ${ }^{3}$ Adina Portrau szerint a két ítélet azt is jelezheti, hogy az uniós bíróság immáron olyan területre merészkedett, amely eleddig a strasbourgi emberi jogi bíróság „felségterülete” volt a vallásszabadság tekintetében, és kérdéses, hogy az európai emberi jogi rezsimek viszonya hogyan fog alakulni a jövőben. ${ }^{4}$

A következő ország, az EU egyik „legkeletibb” tagállama, Bulgária. Az EUB-nak a Milkova-ügyben ${ }^{5}$ hozott ítélete szerint a 2000/78/EK tanácsi irányelv, valamint a fogyatékossággal élő személyek jogairól szóló ENSZ-egyezmény (CRPD) és az Európai Unió Alapjogi Chartája alapján nem ellentétes az uniós joggal egy olyan nemzeti elöírás, amely bizonyos fogyatékossággal élő munkavállalók számára elbocsátás esetén különleges előzetes védelmet biztosít, miközben nem biztosít ilyen védelmet az ugyanazon fogyatékossággal élő köztisztviselők számára, kivéve ha megállapítható az egyenlő bánásmód elvének sérelme, amelynek vizsgálata a kérdést előterjesztő bíróság feladata. Az eset Delia Ferri szerint azért jelentős, mert itt értelmezte az EUB az EU Alapjogi Charta és a CRPD egymáshoz való viszonyát is: a Charta mintegy alkotmányossági szintre emelkedett, és a vonatkozó irányelvet is a Chartával együttesen kell értelmezni és alkalmazni, míg az ENSZ-egyezményt csak figyelembe kell venni, azaz az uniós jogot „csupán” a CRPD tükrében kell alkalmazni. ${ }^{6}$

2 Achbita-ügy, kérelemszám: C-157/15, ítélet: 14/03/2017.

3 Bougnaoui-ügy, kérelemszám: C-188/15, ítélet: 14/03/2017.

4 Adina Portrau: CJEU Cases C-157/15 Achbita and C-188/15 Bougnaoui - 'Neutrality' Trumps Religious Freedom. Völkerrechtsblog, 2017. március 24.

5 C-406/15. számú ügy: Petya Milkova kontra Izpalnitelen direktor na Agentsiata za privatizatsia i sledprivatizatsionen kontrol, ECLI:EU:C:2017:198.

6 Delia Ferri: The Unorthodox Relationship between the EU Charter of Fundamental Rights, the UN Convention on the Rights of Persons with Disabilities and Secondary Rights in the Court of Justice 
Dániával folytatjuk, amely az EU egyik legmagasabb életszínvonallal rendelkező tagállama. Itt egy igencsak érdekes eset hívta fel magára a figyelmet: az elhízás volt a jogeset központi eleme. Az EUB a Kaltoft-ügyben ${ }^{7}$ azt állapította meg, hogy az uniós jog nem mondja ki általános elvként önmagában az elhízás alapján történő hátrányos megkülönböztetés tilalmát a foglalkoztatás és munkavégzés során. Ez azért érdekes, mert van olyan nemzetközi jogforrás, amely alapján más a helyzet: a CRPD-be ütközhet az ilyen típusú megkülönböztetés. Akkor történik ez, amikor a munkavállaló elhízása már egyenesen „fogyatékosságnak” tekinthető. Ilyen az, amikor ez az állapot olyan korlátozottsággal jár, amely különösen valamilyen hosszan tartó testi, szellemi vagy lelki ártalmon alapul, és korlátozhatja az adott személy teljes, hatékony és más munkavállalókkal egyenlő szerepvállalását a munkahelyén. Bár az EUB nem hozott egyértelmü döntést Krista Nadakavukaren Schefer szerint, de ez az ítélet tekinthető az első lépésnek a CRPD alkalmazása, pontosabban szólva annak megismertetése tekintetében a fogyatékosság, az elhízottság és a hátrányos megkülönböztetés hármasa terén. ${ }^{8}$

Egy másik, az úgynevezett DI-ügyben ${ }^{9}$ az életkoron alapuló hátrányos megkülönböztetés tilalma kapcsán az EUB a 2000/78/EK tanácsi irányelv alapján a magánszemélyek közötti jogvitában is az uniós joggal ellentétesnek találta az olyan nemzeti szabályozást, amelynek értelmében a munkavállaló nem jogosult végkielégítésre, ha a munkáltató által fizetett öregségi nyugdíjra jogosult olyan nyugdíjbiztosítási rendszer keretében, amelybe e munkavállaló 50 . életévének betöltését megelőzően lépett be. Ezt arra való tekintet nélkül lehet alkalmazni, hogy a munkavállaló a munkaeröpiacon maradást vagy a nyugdíjba vonulást választja. Ezzel a nemzeti jog az életkoron alapuló hátrányos megkülönböztetés tilalmának általános elvével ellentétes rendelkezésének alkalmazásával kapcsolatban is döntött az EUB, felülírva a nemzeti jog idevágó, ellentétes előírásait. Ez az ügy Elena Gualco szerint később - a Dán Legfelső Bíróság álláspontjának köszönhetően - immáron nyilvánvalóan rávilágított arra a konfliktusra is, hogy valójában ki legyen a legfelsőbb joghatóság és mennyiben érvényesül(het) az uniós jog elsőbbsége a nemzeti jog felett. ${ }^{10}$ Megjegyzendő, hogy a később tárgyalandó, többi hasonló eset figyelembevételekor érdemes tudni azt, hogy Beryl ter Haar szerint az életkor alapján történő hátrányos megkülönböztetés mint kérdéskör különösen 2004 óta a 2000/78/EK irányelv átültetésére megállapított

Case Law on Disability Discrimination. European Constitutional Law Review, 16. (2020), 2. 295.

7 C-354/13. számú ügy: Fag og Arbejde (FOA) kontra Kommunernes Landsforening (KL), ECLI:EU:C:2014:2463.

8 Krista Nadakavukaren Schefer: Fag og Arbejde v. Kommunernes Landsforening (CJEU). International Legal Materials, 54. (2015), 4. 735-746.

9 C-441/14. sz. ügy: Dansk Industri (DI), agissant pour Ajos A/S kontra Sucession Karsten Eigil Rasmussen, ECLI:EU:C:2016:278.

10 Elena Gualco: „Clash of Titans 2.0”. From Conflicting EU General Principles to Conflicting Jurisdictional Authorities: The Court of Justice and the Danish Supreme Court in the Dansk Industri Case. European Papers, 2. (2017), 1. 229. 
határidejének lejártát, valamint a CRPD 2006-os elfogadását követően jelent meg erősebben az EUB gyakorlatában. ${ }^{11}$

Egy harmadik eset is arra világít rá, hogy a magas, 80 év körüli várható élettartam miatt az idősekkel kapcsolatos jogesetek vélhetően strukturálisan kiemelten relevánsak Dániában. Az idősebb munkavállalókat érintő végkielégítéssel kapcsolatban az Ingeniørforeningen i Danmark-ügyben ${ }^{12}$ az EUB úgy határozott, hogy nem ellentétes az uniós joggal az olyan nemzeti szabályozás, amely szerint a munkáltató az ugyanazon vállalkozásnál legalább 12, 15 vagy 18 évig folyamatosan alkalmazott munkavállalónak való felmondás esetén a munkavállaló munkaviszonyának megszünésekor egy-, két-, illetve háromhavi munkabérnek megfelelő összeget köteles fizetni. Ugyanakkor van egy olyan megszorítás, amely az idősek tovább foglalkoztatásának bizonyos fokú, végső soron a munkaadók kötelezettségei tekintetében rugalmasabb eszközeként, illetve az idősebb munkavállalók korlátozásaként is értelmezhető, ha megfelelően objektív és észszerủ módon igazoltnak, illetve az e cél eléréséhez megfelelő és szükséges eszköznek minősül ez az előírás, ugyanis az említett összeg nem jár abban az esetben, ha a munkavállalónak a munkaviszonya megszűnésekor lehetősége volt arra, hogy az általános nyugdíjrendszerben öregségi nyugdíjban részesüljön. Hős Nikolett szerint így az EUB egy olyan - szociális szempontokat is érvényesítő - álláspontra helyezkedett, hogy a végkielégítés lehetőségének megvonásakor figyelembe kell venni az idősebb munkavállalók esetében a rájuk vonatkozó hosszú távú jövedelemveszteséget is, valamint a nyugdíjellátás igénybevételének a lehetőségét. ${ }^{13}$

A szintén skandináv, hasonlóan jó mortalitási és várható élettartammal rendelkező Finnországgal folytatjuk a vizsgálódásunkat. Az EUB a 2000/78/EK tanácsi irányelv alapján úgy döntött a Korkein hallinto-oikeus által benyújtott előzetes döntéshozatal iránti kérelem ügyében, ${ }^{14}$ hogy a nyugdíjból származó jövedelmet terhelő kiegészítő adóra vonatkozó tagállami szabályozás nem tartozik sem ezen irányelv, sem - következésképpen - az Alapjogi Charta 21. cikk (1) bekezdésének tárgyi hatálya alá. Így a tagállami adópolitika révén nem valósul meg az életkoron alapuló hátrányos megkülönböztetés, ami viszont a tagállami hatóságok számára biztosít enyhébb szabályozási kötelezettségeket a hátrányos megkülönböztetés területén az idősebb munkavállalók tekintetében.

Továbbá még két hasonló, folyamatban lévő ügy van jelenleg az EJEB előtt a nyugdíjak magasabb kulccsal történő adóztatása kapcsán is. ${ }^{15} \mathrm{~A}$ holland Legfelső Bíróság főtanácsnoka, René Niessen szerint az eset érdekessége az, hogy valójában (itt is) ellentmondás található az uniós és a strasbourgi bíróság gyakorlata közt, ugyanis

11 Beryl ter Haar: Is the CJEU Discriminating in Age Discrimination Cases? Erasmus Law Review, (2020), 1.

12 C-515/13. számú ügy: Ingeniørforeningen i Danmark kontra Tekniq, ECLI:EU:C:2015:115.

13 Hős Nikolett: Áthidalható-e az irányelvek horizontális közvetlen hatályát kizáró joggyakorlat által teremtett joghézag az Alapjogi Charta segítségével? Pázmány Law Working Papers, (2015), 6. 1-7.

14 C-122/15. számú. ügy: A Korkein hallinto-oikeus (Finnország) által benyújtott előzetes döntéshozatal iránti kérelem, ECLI:EU:C:2016:391.

15 Taipale-ügy (kérelemszám: 5855/18), Tulokas-ügy (kérelemszám: 54854/18). 
az Emberi Jogok Európai Egyezménye alapvetően nem teszi lehetővé az életkor szerinti megkülönböztetést, ideértve az adózást is. Niessen úgy látja, hogy ez azért lehetséges, mert ebben a kérdéskörben az életkoron alapuló hátrányos megkülönböztetés tilalma a szakképzéshez és a foglalkoztatási feltételekhez való hozzáférést elősegítő adószabályokra vonatkozik csak, ugyanis ez a követelmény általában nem érvényes az uniós jogban, és ebből következően nem alkalmazható a 2000/78 irányelv hatályán kívül eső adóügyekben. Így továbbra is a nemzeti bíróság feladata annak megállapítása, hogy az életkoron alapuló hátrányos megkülönböztetés észszerű és objektív célt szolgál-e, valamint szükséges-e e cél eléréséhez. ${ }^{16}$

Folytassuk Franciaországgal! A kor alapján a foglalkoztatás területén történő hátrányos megkülönböztetés témájában 2015 októberében született releváns uniós bírósági ítélet a francia jog vonatkozásában: az O-ügy. ${ }^{17}$ Ennek értelmében az életkoron alapuló hátrányos megkülönböztetés tilalmának az Európai Unió Alapjogi Chartája 21. cikkében megfogalmazott és a többször idézett 2000/78/EK tanácsi irányelvvel pontosított elvét úgy kell értelmezni - méghozzá most a fiatalabb munkavállalók rovására -, hogy azzal nem ellentétes az olyan nemzeti jogszabály, amely a határozott időre szóló munkaszerződés megszűnésekor az iskolai vagy egyetemi szünet ideje alatti időszakra eső, munkabér-kiegészítésként járó juttatást nem folyósítja a fiatal munkavállalónak. Ezzel lényegében - ter Haar szerint - az EUB azt jelentette ki, hogy a fiatal munkavállaló nincs összehasonlítható helyzetben az idősekhez képest, akik egy határozott idejű munkaviszony megszűnése esetén rosszabb helyzetbe kerülnének, részben az ország munkaerőpiaci sajátosságainak köszönhetően. Ter Haar úgy véli - a jelen tanulmányban bemutatott másik nyolc esetet is figyelembe véve -, hogy az EUB következetlen az életkor alapján történő diszkrimináció értelmezésekor, így nem beszélhetünk egységes és egyértelmü jogalkalmazásról. ${ }^{18}$ Végezetül Franciaországot egy másik témában, a szakszervezeti jog kapcsán a strasbourgi EJEB elítélte a Matelly-ügyben ${ }^{19}$ amiatt, hogy a fegyveres erők tagjai egészen 2015-ig nem vehettek részt szakmai szervezetek, szövetségek munkájában, amely ellentétesnek bizonyult a nemzetközi joggal az EJEB szerint.

Görögországban nem a kor alapján történő hátrányos megkülönböztetés gyakorlata került a figyelem középpontjába a fegyveres testületeknél, hanem bizonyos fizikai adottság. A Kalliri-ügy ${ }^{20}$ során az EUB megállapította, hogy a férfiak és a nők közötti egyenlő bánásmód elvének a munkavállalás, a szakképzés, az előmenetel és a munkakörülmények terén releváns az 1976. február 9-i 76/207/EGK tanácsi irányelv. Ennek rendelkezései alapján az uniós joggal ellentétes az a tagállami szabályozás és gyakorlat, amely egy rendőriskolába történő felvételi vizsgán való részvételt a jelentkező

16 René Niessen: Age discrimination in taxation. Tax E Legal Excellence, 2019. szeptember 12.

17 C-432/14 számú ügy: O kontra Bio Philippe Auguste SARL, ECLI:EU:C:2015:643.

18 Ter Haar (2020): i. m.

19 Kérelemszám: 10609/10, ítélet: 02/01/2015.

20 C-409/16 számú ügy: Ypourgos Esoterikon és Ypourgos Ethnikis paideias kai Thriskevmaton kontra Maria-Eleni Kalliri, ECLI:EU:C:2017:767. 
nemétől függetlenül legalább $170 \mathrm{~cm}$-es testmagassághoz köti. Az ügynek van olyan aspektusa Uladzislau Belavusau szerint, hogy ez akár a faji megkülönböztetést is jelentheti, hiszen a testmagasság tekintetében példának okáért a kínai származásúak általában hátrányban lehetnek a hollandokkal szemben. (A fegyveres testületekkel kapcsolatos EUB ítélkezési gyakorlat is ellentmondásos mind a Sorondo-, mind pedig a Vital Pérez-ügy kapcsán is, ahogy később látni fogjuk. $)^{21}$

A nemrégiben, 2019-ben lezárult Monachos Eirinaios-ügyben ${ }^{22}$ az EUB egy érdekes, részben vallási vonatkozású jogvita végére tett pontot a görög jog tekintetében. Az ügy során az EUB megállapította, hogy az uniós joggal ellentétes az a nemzeti jogszabály, amely abból az okból, hogy a szerzetesi minőség és az ügyvédi hivatás gyakorlása e jogszabály szerint összeegyeztethetetlen, a saját tagállamának hatáskörrel rendelkező hatóságánál ügyvédként bejegyzett szerzetesnek megtiltja, hogy a fogadó tagállam hatáskörrel rendelkező hatóságánál - az ügyvédi hivatásának a fogadó tagállamban a saját tagállama szakmai címével történő gyakorlása céljából - bejegyeztesse magát. Ennek ellenére az EUB - Rebecca Zahn szerint - nem teremtett egyértelmủ helyzetet, hiszen valójában az athéni ügyvédi kamarának bár be kellene jegyeznie a ciprusi ügyvéd-szerzetest, de azonnal el is bocsáthatja gyakorlat és a "függetlenség” hiánya miatt, és így az EUB elmulasztotta az arányossági tesztre vonatkozó útmutatás kidolgozását. ${ }^{23}$

Hollandiában is terítékre került a kor alapján és a foglalkoztatás területén történő hátrányos megkülönböztetés témája: 2016-ban a C-548/15. számú ügyben a 30. életévüket be nem töltött személyek számára bizonyos feltételek mellett az EUB megengedi a szakképzési költségek teljes összegének az adóköteles jövedelemből történő levonását, míg a 30. életévüket betöltött személyek esetében már korlátozza az adólevonási jogot. A bíróság szerint akkor nem történik hátrányos megkülönböztetés, ha - az EUB által rendszeresen használt formulával fogalmazva - a szabályozás jogszerủ foglalkoztatás- és munkaerőpiac-politikai céllal objektív és észszerủ módon igazolható, valamint e cél elérésének eszközei megfelelőek és szükségesek. Ter Haar szerint ez eset az úgynevezett „középkorúak” megkülönböztetését jelenti, ugyanakkor azért tartja arányosnak és szükségesnek ezt a korlátozást, mert vélelmezhetően - lényegben ismét egy szociális szempontú érvelés alapján - a 30 év felettiek már jobb anyagi helyzetben lehetnek. ${ }^{24}$ Ha már az életkoron alapuló hátrányos megkülönböztetés témája Hollandia esetében felmerült, akkor Îrország esetében fontos kiemelni - szintén Ter Haar többször idézett tanulmánya szerint -, hogy a 2008-2009-es pénzügyi válság árnyékában született ítéletekhez hasonlóan, amikor a tagállamok megszorító intézkedéseket hoztak és lényegében a szociális szempontokat mellőz-

21 Uladzislau Belavusau: Height Discrimination in EU Law: The Case of Kalliri (C-409/16) at the Court of Justice. European Law Blog, 2018. június 11.

22 Kérelemszám: 431/17, ítélet: 07/05/2019.

23 Rebecca Zahn: 'Can a man serve two masters'? The Court of Justice decides whether monks can be banned from being lawyers. EU Law Analysis, 2019. május 28.

24 Ter Haar (2020): i. m. 
ték az EUB gyakorlatában - a Horgan és Keegan-ügy ${ }^{25}$ releváns ebben a vonatkozásban - és az európai bírósági fórum szintén nem találta jogsértőnek egy meghatározott időponttól az új tanárok felvételekor kevésbé kedvező bértábla és fizetési fokozatba való besorolás alkalmazását előíró nemzeti jogszabályt.

A foglalkoztatás területén, pontosabban az állami szervek egymáshoz való viszonyrendszerében megjelenő érdekes eset volt az ír igazságügyi és esélyegyenlőségi miniszter és a nemzeti rendőrség főkapitánya (Commissioner of An Garda Siochána) közötti vita, amely a 2000/78/EK irányelvvel és az egyenlő bánásmódról szóló törvényekkel állítólagosan ellentétes intézkedések vagy határozatok ellen benyújtott kérelmek elbírálása kapcsán zajlott. Itt a felek arra a kérdésre keresték a választ elözetes döntéshozatali eljárásban, hogy az uniós jog egy meghatározott területen való alkalmazásának biztosítása céljából jogszabály által létrehozott országos szerv (autonóm államigazgatási szerv) mellőzheti-e az uniós joggal ellentétes nemzeti jogszabály alkalmazását. Az EUB úgy döntött, hogy az uniós jogot, és különösen az uniós jog elsőbbségének elvét, tágan kell értelmezni, egyszersmind úgy, hogy azzal ellentétes az olyan nemzeti szabályozás, amelynek értelmében az uniós jog valamely meghatározott területen való alkalmazásának biztosítása céljából jogszabály által létrehozott országos szerv nem rendelkezik hatáskörrel arra, hogy mellőzze valamely, az uniós joggal ellentétes nemzeti jogszabály alkalmazását.

Végezetül a nők közötti esélyegyenlőség és egyenlő bánásmód elvének a foglalkoztatás és munkavégzés területén történő megvalósításáról szóló, 2006. július 5-i 2006/54/EK európai parlamenti és tanácsi irányelv szerint egy speciális élethelyzet alapján Írország esetében találta igazoltnak a nemen alapuló hátrányos megkülönböztetés gyakorlatát az EUB, ha egy női munkavállalótól - olyan anyai minőségében, aki béranyaságról szóló megállapodás keretében vállalt gyermeket - megtagadják a szülési szabadsággal egyenértékủ fizetett szabadság kiadását. ${ }^{26}$ Továbbá az is megállapítást nyert, hogy nem minősül fogyatékosságon alapuló hátrányos megkülönböztetésnek, ha megtagadják a szülési vagy az örökbefogadási szabadsággal egyenértékű fizetett szabadság kiadását az olyan női munkavállalótól, aki gyermek kihordására nem képes, és aki béranyaságról szóló megállapodást kötött. Geert De Baere a Cambridge Law Journal 2015-ös számában írt elemzése szerint - bár hivatkozott rá az eljárás során az ügyfél - a CRPD vizsgálatára nem került sor érdemben, és ez azt is jelenti, hogy - utalva Tanács kontra Stichting Natuur en Milieu and Pesticide Action Network Europe ügyre ${ }^{27}$ - ellentmondásos maradt az EUB ítélkezési gyakorlata a nemzetközi jogi egyezmények alkalmazása tekintetében. ${ }^{28}$ (Megjegyzés: De Baere álláspontja 2015-ös keltezésű, lásd a témában Delia Ferri álláspontját a Milkova-ügy kapcsán.)

25 C-154/18 számú ügy: Tomás Horgan és Claire Keegan kontra Minister for Education \& Skills és társai, ECLI:EU:C:2019:113.

26 Z.-ügy kérelemszám: C-363/12, ítélet: 18/03/2014.

27 C-404/12 P és C-405/12 P, EU:C:2015:5.

28 Geert De Baere: Shall I be Mother? The Prohibition on Sex Discrimination, the UN Disability Convention, and the Right to Surrogacy Leave under EU Law. The Cambridge Law Journal, 74. (2015), 1. 48. 
Írországhoz hasonlóan Lengyelországban is az életkor alapján történő hátrányos megkülönböztetés volt a téma a 2000/78/EK tanácsi irányelv alkalmazása kapcsán: az EUB úgy határozott 2019 júniusában, hogy nem valósul meg közvetett hátrányos megkülönböztetés akkor, ha egy meghatározott időponttól az új tanárok felvételekor kevésbé kedvező bértáblába és fizetési fokozatba való besorolás alkalmazását írja elő a jogszabály, mint amilyeneket az ezen intézkedést megelőző szabályok értelmében az ezen időpontot megelőzően felvett tanárok tekintetében korábban alkalmaztak. ${ }^{29}$ Ugyanakkor a Bizottság kontra Lengyelország ügyben ${ }^{30}$ már az uniós joggal ellentétesnek találta a EUB azt, hogy a legfelső bíróság bíráinak a nyugdíjkorhatárát lejjebb szállították, kirobbantva az úgynevezett jogállamisági vitát az uniós intézmények és Lengyelország között.

Németország rendelkezik a legnagyobb és egyben a legfontosabb gazdasággal és munkaerőpiaccal az EU-ban, így nem közömbös, hogy ott milyen esetjog fejlődik a 2000/78/EK tanácsi irányelv alapján. Az EUB elutasított egy olyan érvelést egy panaszos részéről, aki egy álláspályázat során nem konkrét munkalehetőséget, hanem pusztán formális pályázói jogállást kívánt szerezni, méghozzá kizárólag kártérítési igény érvényesítése céljából. Az EUB úgy utasította el a panaszos kérelmét a Kratzerügyben, ${ }^{31}$ hogy valójában az uniós jog által megkövetelt elemek bár fennálltak - tette hozzá a Bíróság -, egy ilyen helyzet joggal való visszaélésnek minősülhet. A németországi Baker \& McKenzie munkajogászai által 2016 augusztusában jegyzett vélemény szerint ezzel az EUB elejét vette a megélhetési pereskedőknek, akik rosszhiszemüen jelentkeznek álláshirdetésekre azért, hogy elutasítás esetén egyébként jogellenesnek (tünő) feltételek (kor, vallás stb.) miatt kártérítést követelhessenek. ${ }^{32}$

2018-ban - a korábban említett görög jogesethez némiképp kapcsolódó témában, azaz a vallásszabadság területén - az EUB egy egyház általi foglalkoztatással kapcsolatos ügyben (Egenberger kontra Evangelisches Werk für Diakonie und Entwicklung e.V.) azt állapította meg, hogy a vallási hovatartozásnak az egyház körében betöltött állás követelményeként alkalmasnak kell lennie arra, hogy hatékony bírósági felülvizsgálat tárgyát képezze, vagyis megtámadható legyen a foglalkoztatással összefüggő konkrét döntés egy egyházi szervezetnél betöltendő (világi) állás kapcsán. Ez azt jelenti, hogy a követelményrendszernek a vonatkozó szakmai tevékenység jellegére és gyakorlásának feltételrendszerére, valamint az érintett egyház vagy szervezet szellemiségére tekintettel szükségesnek és objektív módon meghatározottnak kell lennie, valamint összhangban kell állnia az arányosság elvével is. Ezzel azt mondta ki a Bíróság, hogy önmagában a vallásosság (illetve annak hiánya) nem igazolhat

29 C-619/18. számú ügy: Bizottság kontra Lengyelország, ECLI:EU:C:2019:531.

30 C-192/18. számú ügy, ECLI:EU:C:2019:924.

31 C-423/15. számú ügy: Nils-Johannes Kratzer kontra R+V Allgemeine Versicherung AG, ECLI:EU:C:2016:604.

32 Burkard Goepfert - Thomas Meyerhans: ECJ Rejects Compensation Claims for ,Mock' Applications. Baker \& McKenzie, Hot topics, Employment Law, (2016), augusztus. 
(aránytalan) megkülönböztetést a munkavállalók tekintetében. ${ }^{33}$ Colombi Ciacchi szerint az EUB ezzel a döntésével egyértelműen elismerte az EU Alapjogi Chartájában foglalt bizonyos jogok közvetlen horizontális hatályát is, amelynek következményeként a Charta hatékony jogorvoslathoz és a tisztességes eljáráshoz való jogról szóló 47. cikkét mintegy teljes jogúnak nyilvánította, ideértve a magánperek elbírálását is. Ezen túlmenően az ítélet jelentőségét az is adja, hogy az EUB a Charta 21. (megkülönböztetés tilalma) és 47. cikkének közvetlen (horizontális) hatályának összeegyeztethetőségét mondta ki azzal, hogy a nemzeti bíróságoknak kell egyensúlyban tartaniuk a konkuráló alapvető jogokat. ${ }^{34}$

Hasonlóan vallási jellegü kérdésben, az IR kontra JQ-ügyben ${ }^{35}$ született döntés a munkavállalók vallásgyakorlása tekintetében, méghozzá szintén 2018-ban. Eszerint a valláson alapuló hátrányos megkülönböztetés tilalmával ellentétes, ha a katolikus kórháznál egy katolikus orvost elbocsátanak házasságának felbontása és újabb házasságkötése alapján. A katolikus orvossal szemben támasztott azon követelmény, amely szerint tiszteletben kell tartania a házassági köteléknek a katolikus egyház álláspontja szerinti szent és elszakíthatatlan jellegét, nem képezhet megalapozott szakmai követelményt, és még kevésbé minősül lényeges és igazolt szakmai követelménynek az uniós jog szerint az EUB ítélete értelmében. Eszerint valamely személy vallásán vagy meggyőződésén alapuló eltérő bánásmód akkor nem minősül hátrányos megkülönböztetésnek, ha - ezeknek a tevékenységeknek a jellege vagy gyakorlásuk feltételrendszere alapján - az adott személy vallása vagy meggyőződése lényeges, törvényes és igazolt szakmai követelménynek bizonyul, tekintettel a konkrét szervezet szellemiségére. Colombi Ciacchi úgy látja, hogy bár az Egenberger és az IR kontra JQ ügyekben az EUB bizonyos mértékben korlátozta a vallási szervezetek autonómiáját, az uniós taláros testület nem avatkozott be a nemzeti bíróságok szabadságába azzal, hogy kimondta: a versengő alapvető jogokat a nemzeti alkotmányos értékek szerint kell kiegyensúlyozni, amely azt is jelenti egyben, hogy az uniós jog képes hatékonyan érvényesülni a nemzeti alkotmányossággal összhangban. ${ }^{36}$

Speciális esetet jelent egy szintén friss, 2018-as keltezésű, a fogyatékossággal élő munkavállalók helyzete kapcsán született európai bírósági ítélet. ${ }^{37}$ Ebben az EUB az említett 2000/78/EK tanácsi irányelvvel ellentétesnek találta a kollektív szerződésben szereplő olyan rendelkezéseket, amelyek előírják, hogy a munkahelyét elvesztett munkavállalónak, megfelelő megélhetése biztosításának céljából, a kötelező nyugdíjbiztosítási rendszer szerinti öregségi nyugdíjra való jogosultsága eléréséig járó átmeneti kiegészítő támogatás folyósítása megszűnik, amikor e munkavállaló teljesíti

33 C-414/16. számú ügy: Vera Egenberger kontra Evangelisches Werk für Diakonie und Entwicklung e.V., ECLI:EU:C:2018:257.

34 Aurelia Colombi Ciacchi: The Direct Horizontal Effect of EU Fundamental Rights. European Constitutional Law Review, 15. (2019), 2. 294-305.

35 C-68/17. számú ügy: IR kontra JQ, ECLI:EU:C:2018:696.

36 Colombi Ciacchi (2019): i. m.

37 C-312/17. számú. ügy: Surjit Singh Bedi kontra Bundesrepublik Deutschland és Bundesrepublik, ECLI:EU:C:2018:734. 
az ahhoz előírt feltételeket, annak érdekében, hogy e rendszer alapján a súlyos fogyatékossággal élő személyek előrehozott öregségi nyugdíjában részesüljön, amely fogyatékosságon alapuló hátrányos megkülönböztetésnek bizonyul.

Olaszország az egyik legjobb mutatókkal rendelkezik az egészségben eltöltött és a várható élettartam tekintetében, így nem véletlen, hogy az Európai Unió Bíróságának az életkor alapján történő ítélkezése a társadalom figyelmének a középpontjában áll. Az EUB-nak a hátrányos megkülönböztetés tekintetében - a szakirodalom által kiemelten és többször hivatkozott - Abercrombie-ügyben ${ }^{38}$ hozott döntése azt jelenti, hogy az EUB szerint az európai joggal nem ellentétes az olyan nemzeti rendelkezés, amely lehetővé teszi a munkáltató számára, hogy 25 év alatti munkavállalóval - a munkavégzés jellegétől függetlenül - idénymunkára szóló munkaszerződést kössön, és ezt a munkavállalót önmagában a 25. életévének betöltése okán elbocsássa. Ugyanakkor Jule Mulder szerint az EUB döntése alapvetően azért előremutató, mert egyrészt sztereotip vélekedést erősítő munkaerőpiaci intézkedések jogosultságát kérdőjelezte meg azzal, hogy a tagállamokat arra késztetik, hogy azonosítsák a széles körben elterjedt ifúsági (és egyéb) munkanélküliség valódi strukturális okait, ahelyett, hogy bizonyos korcsoportoktól visszavonnák a további munkajogi védelmet a sérülékenységükre vonatkozó sztereotip feltevések és a munkaerőpiac liberalizációjával kapcsolatos megalapozatlan spekulációk alapján a más csoport(ok) foglalkoztatottságának növelése érdekében. Az EUB által felállított arányossági teszt Mulder álláspontja szerint arra kényszeríti a nemzeti bíróságokat, hogy a statisztikai bizonyítékok és a tágabb jogi kontextus alapján álló döntéseket hozzanak a kérdéses munkaerőpiaci intézkedések megfelelőségéről és szükségességéről. Ugyanakkor félő az is, hogy „high standard of proof” (75. pont) alkalmazása során az elvárt releváns statisztikai vagy más felhasználható adatok nem állnak széleskörűen rendelkezésre. ${ }^{39}$

A jelen tanulmány alapjául szolgáló korábbi elemzésem ${ }^{40}$ szerint az EUB elmúlt öt évben hozott ítéleteit alapul véve a munkavállalók és közszolgálatban dolgozók jogainak védelme tekintetében az Osztrák Köztársaság érdemelte ki a legaktívabb tagállam „címet” az ügyek számát tekintve a 2000/78/EK tanácsi irányelv kritikus alkalmazása szempontjából. Leggyakrabban a kor alapján vélelmezett hátrányos megkülönböztetés témája merült fel Ausztriában is. Különösen a 18. életév betöltését megelőző tanulmányi, képzési és szolgálati idők, tapasztalatok beszámítását érintő ügyek voltak problémásak, többek közt a fizetési fokozatokba lépéshez szükséges időtartam

38 C-143/16 számú ügy: Abercrombie \& Fitch Italia Srl kontra Antonino Bordonaro, ECLI:EU:C:2017:566.

39 Jule Mulder: Age discrimination is not in fashion: AG Bobek's Opinion in Abercrombie \& Fitch v Bordonaro. University of Bristol Law School Blog, 2017. május 1.

40 Lásd a Trócsányi László - Lovászy László Gábor (szerk.): Európai körkép - Európai értékek és megvalósulásuk az Európai Unió tagállamaiban az adatok és számok tükrében. Budapest, Ludovika Egyetemi Kiadó, 2020. kötetben szereplő minden fö fejezetben lévő $A$ hátrányos megkülönböztetés elleni küzdelem egyes kérdéseiről címủ 3. alfejezeteket. 
figyelembevétele kapcsán. Az uniós bíróság a Felber-ügyben ${ }^{41}$ azt állapította meg, hogy nem ütközik hátrányos megkülönböztetés tilalmába a 18. életév előtt szerzett munkatapasztalat, tanulmányok be nem számíthatósága a nyugdíjjogosultságra alapot adó időtartamokból. Ugyanakkor, teszi hozzá Rab Henriett és Zaccaria Márton Leó, ${ }^{42}$ az EUB azt a munkaerőpiaci szempontot is méltányolta a Schmitzer-ügyben, ${ }^{43}$ hogy nem számít indokolatlan előnynek az, ha valaki már 18 éves kora előtt munkát végzett, illetőleg ebben az esetben nem különül el egymástól a két veszélyeztetett csoport - azaz a fiatalok és az idősek - jogi védelme, hiszen a szolgálati idő számítása nem életkortól függ. (Lásd még a témában: Starjakob-ügy ${ }^{44}$ és Lesar-ügy. ${ }^{45}$ )

Hasonló jellegü döntés született a vállalkozások munkavállalói esetében is a kor alapján történő megkülönböztetés tekintetében az úgynevezett Stollwitzer-ügyben. ${ }^{46}$ Az előmenetelre vonatkozó osztrák szabályozás kapcsán az uniós joggal ellentétesnek bizonyult egy olyan visszamenőleges hatállyal életbe lépő nemzeti szabályozás, amely az életkoron alapuló hátrányos megkülönböztetés megszüntetése érdekében úgy rendelkezett, hogy a szerződéses alkalmazottak új díjazási és előmeneteli rendszerbe való átsorolásakor e szerződéses alkalmazottak első besorolását a korábbi rendszer szerinti utolsó illetményük függvényében kell meghatározni (Österreichischer Gewerkschaftsbund-ügy). ${ }^{47}$

A Leitner-ügyben ${ }^{48}$ is hasonló témában született döntés: uniós jogba ütközik az a nemzeti szabályozás, amely az életkoron alapuló hátrányos megkülönböztetés megszüntetése érdekében úgy rendelkezik, hogy a szolgálatban álló köztisztviselők új díjazási és előmeneteli rendszerbe való átsorolásakor e köztisztviselők első besorolását a korábbi rendszer szerinti utolsó illetményük függvényében kell meghatározni. A 2019-es év friss döntéssel zárult, amely a női munkavállalókat érintette különösen érzékenyen: a Schuch-Ghannadan-ügyben ${ }^{49}$ az uniós joggal ellentétesnek minősült az a gyakorlat, amely a határozott időre alkalmazott munkavállalók esetében a munkaviszonyok maximális időtartamát hosszabb időszakban rögzítette a részmunkaidőben foglalkoztatott munkavállalók számára, mint a velük összehasonlítható, teljes munkaidőben foglalkoztatott munkavállalók számára, ha bebizonyosodott, hogy

41 C-529/13 számú ügy: Georg Felber kontra Bundesministerin für Unterricht, Kunst und Kultur, ECLI:EU:C:2015:20.

42 Rab Henriett - Zaccaria Márton Leó: Elősegítheti-e a munkaerőpiaci egyensúlyt az életkori alapú diszkrimináció tilalma? Miskolci Jogi Szemle, 12. (2017), 1. 56.

43 C-530/13 számú ügy: Leopold Schmitzer kontra Bundesministerin für Inneres, ECLI:EU:C:2014:2359.

44 C-417/13 számú ügy: ÖBB Personenverkehr AG kontra Gotthard Starjakob, ECLI:EU:C:2015:38.

45 C-159/15 számú ügy: Franz Lesar kontra Beim Vorstand der Telekom Austria AG eingerichtetes Personalamt, ECLI:EU:C:2016:451.

46 C-482/16 számú ügy: Georg Stollwitzer kontra ÖBB Personenverkehr AG, ECLI:EU:C:2018:180.

47 C-24/17 számú ügy: Österreichischer Gewerkschaftsbund, Gewerkschaft Öffentlicher Dienst kontra Republik Österreich, ECLI:EU:C:2019:373.

48 C-396/17 számú ügy: Martin Leitner kontra Landespolizeidirektion Tirol, ECLI:EU:C:2019:375.

49 C-274/18 számú ügy: Minoo Schuch-Ghannadan kontra Medizinische Universität Wien, ECLI:EU:C:2019:828. 
a szabályozás a férfi munkavállalókhoz képest a női munkavállalók jelentősen magasabb arányát érinti negatívan, és nem igazolható objektív módon jogszerủ céllal, illetve ha e cél megvalósításának eszközei nem megfelelőek és nem szükségesek.

Végezetül fontos megemlíteni a szomszédos ország esetében azt is, hogy az Európai Bizottság 2019. január 24-én kötelezettségszegési eljárást indított Ausztria ellen a magyar munkavállalókat is érintő családi pótlék indexálása miatt. A szövetségi parlament 2018. október 24-i döntése alapján 2019. január 1-jétől az Ausztriában dolgozó külföldi munkavállalók származási országában élő gyermekei után a családi pótlékot az adott ország jövedelmi viszonyaihoz igazították volna. ${ }^{50} \mathrm{Ez}$ az európai vendégmunkások szempontjából kedvezőtlen lépésnek minősíthető, hiszen megszegi a szociális biztonsági rendszerek koordinálására vonatkozó uniós szabályokat (883/2004/EK rendelet), ${ }^{51}$ valamint sérti az egyenlő bánásmód elvét is a más tagállam állampolgárságával rendelkező munkavállalók szociális ellátásai és adókedvezményei vonatkozásában (492/2011/EU rendelet). ${ }^{52}$ A vita kiindulópontja az volt, hogy „bér- és szociális dömping" elleni osztrák törvény súlyos adminisztratív akadályokat és drasztikus bírságokat alkalmaz a más tagországokból határon átnyúló szolgáltatást biztosító cégek munkavállalóinak kiküldésére vonatkozóan, ami már a kétoldalú kapcsolatokat is mérgezi.

Románia egy jelentősebb üggyel képviselteti magát ezen a téren, ami nem más, mint az SCMD és társai kontra Ministerul Finanțelor Publice-ügy, ${ }^{53}$ amelyben a bruttó átlagjövedelem kapcsán a közszférában foglalkoztatott munkavállalókat érintő megkülönböztetés tekintetében hozott döntést az EUB. Ez alapján a 2000/78/EK tanácsi irányelv 2. cikkének (2) bekezdését, valamint 3. cikkének (1) bekezdését nem kell alkalmazni olyan nemzeti szabályozás esetében, amely a közszférában foglalkoztatott azon munkavállalók munka- vagy szolgálati viszonyának teljes jogú megszüntetését írja elő, akik egyébként a bruttó átlagjövedelemnél magasabb öregségi nyugellátásban részesülnek, és meghatározott határidőn belül nem döntöttek e munka- vagy szolgálati viszony folytatásáról.

Az elemzés utolsó tagállama, Spanyolország esetében az EUB a Daouidi-ügyben ${ }^{54}$ a munkahelyi balesetek témájában foglalkozott a fogyatékossággal összefüggésben a „hosszan tartó” jelleg meghatározásával, amelynek során ismét - a Németországgal kapcsolatos ügyhöz hasonlóan - a fogyatékos személyekre vonatkozó ENSZegyezmény (CRPD) rendelkezéseivel együtt kezelte ezt a problémát. Ugyanakkor Alex Denny - Emma Vennesson ügyvéd szerzők úgy látják, hogy az EUB nem hozott egyértelmủ és értelmezhető döntést, hiszen nem határozták meg kézzelfogható módon, hogy mi tekintendő hosszan tartó fogyatékosságnak, szemben a brit joggal,

50 Lásd: https://ec.europa.eu/commission/presscorner/detail/hu/IP_19_463

51 Lásd: https://eur-lex.europa.eu/LexUriServ/LexUriServ.do?uri=CONSLEG:2004R0883:20100501:h u:PDF

52 Lásd: https://eur-lex.europa.eu/legal-content/HU/TXT/?uri=celex:32011R0492

53 C-262/14. számú ügy: Sindicatul Cadrelor Militare Disponibilizate în rezervă și în retragere (SCMD) és társai kontra Ministerul Finanțelor Publice, ECLI:EU:C:2015:336.

54 C-395/15 számú ügy: Mohamed Daouidi kontra Bootes Plus SL és társai, ECLI:EU:C:2016:917. 
ahol ez 12 hónapot meghaladó időtartamot felölelő fogyatékosságot jelent a 2010-ben elfogadott Equalty Act alapján. ${ }^{55}$

Ehhez kapcsolódóan - a dán Kaltoft-ügyhöz kapcsolódó témában - a Ruiz Conejero-ügy ${ }^{56}$ alapján az uniós joggal ellentétes az olyan nemzeti szabályozás, amely úgy rendelkezik, hogy a munkáltató felmondhatja a munkavállaló munkaszerződését annak akár igazolt, de rendszeresen ismétlődő távollétei miatt, amennyiben e távollétekre a munkavállaló fogyatékosságának (itt: túlsúly) betudható betegségek miatt kerül sor, feltéve, ha e szabályok - amelyek a munkahelyi hiányzás elleni küzdelem törvényes célját szolgálják - nem lépik túl a szükséges mértéket, aminek megítélése az adott bíróság feladata. Az EUB spanyolországi esetjoggal kapcsolatos még frissebb döntésében, a Nobel Plastiques Ibérica SA-ügyben ${ }^{57}$ a fogyatékossággal kapcsolatosan - a CRPD-egyezményt immáron alapul véve - azt is rögzítette, hogy az olyan egészségi állapot, amely - különösen valamilyen tartósan fennálló testi, értelmi vagy lelki károsodáson alapuló - korlátozottságot eredményez, és ez más egyéb akadállyal együtt korlátozhatja az érintett személy szakmai életben való teljes, hatékony és más munkavállalókkal egyenlő részvételét, fogyatékosságnak minősül, vagyis a munkahelyi megbetegedés is ebbe a kategóriába esik Pecinovsky szerint. ${ }^{58}$ Maga az ítélet is kitér az úgynevezett észszerủ alkalmazkodás követelményére, amit a munkáltatónak (előzetesen) teljesítenie kell.

Végezetül az EUB az életkor alapján történő hátrányos megkülönböztetés formájaként értékelte a Vital Pérez-ügyben ${ }^{59}$ azt, hogy egy helyi rendőrségen a rendőrök esetében a felvételi felső korhatárát 30 évben rögzítették, mert az EUB úgy látta, hogy például a tűzoltókra vonatkozó életkori megkötés (Wolf-ügy) ${ }^{60}$ a magasabb szintű fizikai követelményeknek megfelelő állapot érdekében megáll, míg a rendőrök esetében már nem. Ugyancsak a rendvédelmi szervek kapcsán született uniós bírósági döntés a Sorondo-ügyben, ${ }^{61}$ amelyben viszont azt mondta ki az EUB, hogy a 35 éves felső korhatár előírása nem ütközik uniós jogba, amennyiben a pályázó jelölteknek az adott rendőrségre ruházott „operatív vagy végrehajtási feladatok összességét is el kell látniuk".

A legfontosabb esetjog áttekintése után kijelenthető, hogy önmagában ezeknek az eseteknek a rövid felsorolása is azt mutatja, hogy nincs egyforma két tagállam, nincs azonos életviszony és gyakorlat az uniós tagállamokban, amely azok sokszínüségéből és fejlettségbeli eltérésből fakad. Mindazonáltal ezen esetek szélesebb körü

55 Alex Denny - Emma Vennesson: European Court of Justice: Can Temporary Incapacity of an Unknown Duration Constitute a Disability? Faegre Drinker, 2016. december 31.

56 C-270/16 számú ügy: Carlos Enrique Ruiz Conejero kontra Ferroser Servicios Auxiliares SA és Ministerio Fiscal, ECLI:EU:C:2018:17.

57 C-397/18 számú ügy: DW kontra Nobel Plastiques Ibérica SA, ECLI:EU:C:2019:703.

58 Pieter Pecinovsky: CJEU rules that occupational illness can be seen as a disability. Van Olmen $\mathcal{E}$ Wynant, 2018.

59 C-416/13 számú ügy: Mario Vital Pérez kontra Ayuntamiento de Oviedo, ECLI:EU:C:2014:2371.

60 C-229/08. számú ügy: Colin Wolf v Stadt Frankfurt am Main, ECLI:EU:C:2010:3.

61 C-258/1515 számú ügy: Gorka Salaberria Sorondo kontra Academia Vasca de Policía y Emergencias, ECLI:EU:2016:873. 
értelmezéséhez tágabb összefüggésrendszer szükségeltetik, hiszen ezeknek az eseteknek van egy tágabb társadalmi, szociális kontextusuk is, amelyek nem nélkülözhetők a tisztább kép tekintetében A teljesebb kép érdekében szerkesztettem Trócsányi Lászlóval közösen az Európai körkép - Európai értékek és megvalósulásuk az Európai Unió tagállamaiban az adatok és számok tükrében címủ kötetet, amely 2020 végén jelent meg a Ludovika Egyetemi Kiadó gondozásában.

\section{Irodalomjegyzék}

Baere, Geert De: Shall I be mother? The prohibition on sex discrimination, the UN Disability Convention, and the right to surrogacy leave under EU law. The Cambridge Law Journal, 74. (2015), 1. 44-48. Online: https://doi.org/10.1017/S0008197315000239

Belavusau, Uladzislau: Height Discrimination in EU Law: The Case of Kalliri (C-409/16) at the Court of Justice. European Law Blog, 2018. június 11. Online: https://europeanlawblog.eu/2018/06/11/ height-discrimination-in-eu-law-the-case-of-kalliri-c-409-16-at-the-court-of-justice

Colombi Ciacchi, Aurelia: The Direct Horizontal Effect of EU Fundamental Rights. European Constitutional Law Review, 15. (2019) 2. 294-305. Online: https://doi.org/10.1017/S1574019619000154

Denny, Alex - Emma Vennesson: European Court of Justice: Can Temporary Incapacity of an Unknown Duration Constitute a Disability? Faegre Drinker, 2016. december 31. Online: www.faegredrinker.com/en/insights/publications/2016/12/european-court-of-justice-can-temporaryincapacity-of-an-unknown-duration-constitute-a-disability

Európai Bizottság: A családi ellátások indexálása: a Bizottság kötelezettségszegési eljárást indít Ausztria ellen. (2019. január 24.). Online: https://ec.europa.eu/commission/presscorner/detail/ $\mathrm{hu} / \mathrm{IP} \_19 \_463$

Ferri, Delia: The Unorthodox Relationship between the EU Charter of Fundamental Rights, the UN Convention on the Rights of Persons with Disabilities and Secondary Rights in the Court of Justice Case Law on Disability Discrimination. European Constitutional Law Review, 16. (2020), 2. 275-305. Online: https://doi.org/10.1017/S1574019620000164

Goepfert, Burkard - Thomas Meyerhans: ECJ Rejects Compensation Claims for 'Mock' Applications. Baker E McKenzie, Hot topics, Employment Law, (2016), augusztus. Online: www.bakermckenzie.com/-/media/files/insight/publications/2016/08/ecj-rejects-compensation-claims-formock/nl_germany_mockapplications_aug16.pdf?la=en

Gualco, Elena: „Clash of Titans 2.0”. From Conflicting EU General Principles to Conflicting Jurisdictional Authorities: The Court of Justice and the Danish Supreme Court in the Dansk Industri Case. European Papers, 2. (2017), 1. 223-229. Online: www.europeanpapers.eu/en/system/files/ pdf_version/EP_EF_2017_I_013_Elena_Gualco_00124.pdf

Haar, Beryl ter: Is the CJEU Discriminating in Age Discrimination Cases? Erasmus Law Review, (2020), 1. Online: www.erasmuslawreview.nl/tijdschrift/ELR/2020/1/ELR-D-20-00001/fullscreen

Hős Nikolett: Áthidalható-e az irányelvek horizontális közvetlen hatályát kizáró joggyakorlat által teremtett joghézag az Alapjogi Charta segítségével? Pázmány Law Working Papers, (2015), 6. 1-7. Online: https://plwp.eu/docs/wp/2015/2015-06_Hos.pdf

Mulder, Jule: Age discrimination is not in fashion: AG Bobek's Opinion in Abercrombie \& Fitch v Bordonaro. University of Bristol Law School Blog, 2017. május 1. Online: https://legalresearch. blogs.bris.ac.uk/2017/05/age-discrimination-is-not-in-fashion-ag-bobeks-opinion-in-abercrombie-fitch-v-bordonaro/\#more-630 
Nadakavukaren Schefer, Krista: Fag og Arbejde v. Kommunernes Landsforening (CJEU). International Legal Materials, 54. (2015), 4. 735-746. Online: https://doi.org/10.5305/intelegamate.54.4.0735

Niessen, René: Age discrimination in taxation. Tax \& Legal Excellence, 2019. szeptember 12. Online: www.tax-legal-excellence.com/age-discrimination-in-taxation

Pecinovsky, Pieter: CJEU rules that occupational illness can be seen as a disability. Van Olmen $\mathcal{E}$ Wynant, 2018. Online: www.vow.be/node/146

Portrau, Adina: CJEU Cases C-157/15 Achbita and C-188/15 Bougnaoui - 'Neutrality' Trumps Religious Freedom. Völkerrechtsblog, 2017. március 24. Online: https://doi.org/10.17176/20180326210203

Rab Henriett - Zaccaria Márton Leó: Elősegítheti-e a munkaerőpiaci egyensúlyt az életkori alapú diszkrimináció tilalma? Miskolci Jogi Szemle, 12. (2017), 1. 46-58. Online: www.mjsz.uni-miskolc.hu/files/egyeb/mjsz/201701/6_rabzaccaria.pdf

Trócsányi László - Lovászy László Gábor (szerk.): Európai körkép - Európai értékek és megvalósulásuk az Európai Unió tagállamaiban az adatok és számok tükrében. Budapest, Ludovika Egyetemi Kiadó, 2020.

Zahn, Rebecca: 'Can a man serve two masters'? The Court of Justice decides whether monks can be banned from being lawyers. EU Law Analysis, 2019. május 28. Online: http://eulawanalysis. blogspot.com/2019/05/can-man-serve-two-masters-court-of.html

\section{Jogforrások}

Abercrombie \& Fitch Italia Srl v. Antonino Bordonaro, no.143/16, ECLI:EU:C:2017:566.

Achbita-ügy, no. 157/15.

Surjit Singh Bediv. BundesrepublikDeutschland és Bundesrepublik, no.312/17,ECLI:EU:C:2018:734.

Bizottság v. Lengyelország, no.192/18, ECLI:EU:C:2019:924.

Bizottság v. Lengyelország, no. 619/18, ECLI:EU:C:2019:531.

Bizottság v. Stichting Natuur en Milieu and Pesticide Action Network Europe, no. 404/12 P és no. 405/12 P, EU:C:2015:5.

Bougnaoui-ügy, no.188/15.

Carlos Enrique Ruiz Conejero v. Ferroser Servicios Auxiliares SA és Ministerio Fiscal, no. 270/16, ECLI:EU:C:2018:17.

Colin Wolf v Stadt Frankfurt am Main, no. 229/08, ECLI:EU:C:2010:3.

Dansk Industri (DI), agissant pour Ajos A/S v. Sucession Karsten Eigil Rasmussen, no. 441/14, ECLI:EU:C:2016:278.

DW v. Nobel Plastiques Ibérica SA, no. 397/18, ECLI:EU:C:2019:703.

Az Európai Parlament és a Tanács 883/2004/EK rendelete (2004. április 29.) a szociális biztonsági rendszerek koordinálásáról (EGT és Svájc vonatkozású szöveg) (HL L 200., 2004.6.7.) Online: https://eur-lex.europa.eu/LexUriServ/LexUriServ.do?uri=CONSLEG:2004R0883:20100501:hu: PDF

Az Európai Parlament és a Tanács 492/2011/EU rendelete a munkavállalók Unión belüli szabad mozgásáról, (2011. április 5.), Online: https://eur-lex.europa.eu/legal-content/HU/ TXT/?uri=celex:32011R0492

Fag og Arbejde (FOA) v. Kommunernes Landsforening (KL), no. 354/13, ECLI:EU:C:2014:2463.

Franz Lesar v. Beim Vorstand der Telekom Austria AG eingerichtetes Personalamt, 159/15, ECLI:EU:C:2016:451. 
Georg Felber v. Bundesministerin für Unterricht, Kunst und Kultur, no. 529/13, ECLI:EU:C:2015:20. Georg Stollwitzer v. ÖBB Personenverkehr AG, 482/16, ECLI:EU:C:2018:180.

Gorka Salaberria Sorondo v. Academia Vasca de Policía y Emergencias, no. 258/1515, ECLI:EU:2016:873.

Ingeniørforeningen i Danmark v. Tekniq, no. 515/13, ECLI:EU:C:2015:115.

IR v JQ, no. 68/17.

A Korkein hallinto-oikeus (Finnország) által benyújtott előzetes döntéshozatal iránti kérelem, no. 122/15, ECLI:EU:C:2016:391.

Leopold Schmitzer v. Bundesministerin für Inneres, no. 530/13, ECLI:EU:C:2014:2359.

Schuch-Ghannadan v. Medizinische Universität Wien, no. 274/18, ECLI:EU:C:2019:828.

Martin Leitner v. Landespolizeidirektion Tirol, 396/17, ECLI:EU:C:2019:375.

Mario Vital Pérez v. Ayuntamiento de Oviedo, no. 416/13, ECLI:EU:C:2014:2371.

Matelly-ügy, no. 10609/10.

Mohamed Daouidi v. Bootes Plus SL és társai, no. 395/15, ECLI:EU:C:2016:917.

Monachos-Eirinaios-ügy, no. 431/17

Nils-Johannes Kratzer v. R+V Allgemeine Versicherung AG, no. 423/15, ECLI:EU:C:2016:604.

v. Bio Philippe Auguste SARL, no. 432/14, ECLI:EU:C:2015:643.

ÖBB Personenverkehr AG v. Gotthard Starjakob, 417/13, ECLI:EU:C:2015:38.

Österreichischer Gewerkschaftsbund, Gewerkschaft Öffentlicher Dienst v. Republik Österreich, no. 24/17, ECLI:EU:C:2019:373.

Petya Milkova v. Izpalnitelen direktor na Agentsiata za privatizatsia i sledprivatizatsionen kontrol, no. 406/15, ECLI:EU:C:2017:198.

Sindicatul Cadrelor Militare Disponibilizate în rezervă și în retragere (SCMD) és társai v. Ministerul Finanțelor Publice, no. 262/14, ECLI:EU:C:2015:336.

Taipale-ügy, no. 5855/18.

Tomás Horgan és Claire Keegan v. Minister for Education \& Skills és társai, no. 154/18, ECLI:EU:C:2019:113.

Tulokas-ügy, no. 54854/18.

Vera Egenberger v. Evangelisches Werk für Diakonie und Entwicklung e.V. no. 414/16, ECLI:EU:C:2018:257.

Ypourgos Esoterikon és Ypourgos Ethnikis paideias kai Thriskevmaton v. Maria-Eleni Kalliri, no. 409/16, ECLI:EU:C:2017:767.

Z.-ügy, no. 363/12. 